\title{
PENGEMBANGAN MODUL IPA TERPADU BERBASIS KETERAMPILAN PROSES SAINS UNTUK MENINGKATKAN HASIL BELAJAR DAN KEMAMPUAN BERPIKIR KRITIS SISWA MATERI PENCEMARAN LINGKUNGAN KELAS VII SMPN 1 SUKOLILO
}

\author{
Ratna Kumala Sari ${ }^{1}$, Widha Sunarno ${ }^{2}$, Sri Dwiastuti ${ }^{3}$ \\ ${ }^{1}$ Program Studi Magister Pendidikan Sains FKIP Universitas Sebelas Maret \\ Surakarta, 57126, Indonesia \\ ratnakumala9999@gmail.com \\ ${ }^{2}$ Program Studi Magister Pendidikan Sains FKIP Universitas Sebelas Maret \\ Surakarta, 57126, Indonesia \\ widhasunarno@gmail.com \\ ${ }^{3}$ Program Studi Magister Pendidikan Sains FKIP Universitas Sebelas Maret \\ Surakarta, 57126, Indonesia \\ dwiastuti54@gmail.com
}

\begin{abstract}
Abstrak
Tujuan dari penelitian ini adalah untuk mengetahui karakteristik, keefektifan dan studi kelayakan untuk modul keterampilan proses sains yang terintegrasi dengan isu pencemaran lingkungan (SPSM-EP). Ini adalah penelitian dan pengembangan dengan studi kasus one-shot sebagai desain pra-eksperimental. Model Four-D (Thiagarajan, 1974) yang terdiri dari pendefinisian, perancangan, pengembangan dan diseminasi yang digunakan untuk pengembangan SPSM-EP. Penelitian dilakukan di SMP Negeri 1 Sukolilo dan data dikumpulkan dan dianalisis dengan deskripsi kualitatif kuantitatif. Hasil penelitian menunjukkan bahwa SPSM-EP memiliki kontribusi dan efektif untuk meningkatkan berpikir kritis siswa dan hasil belajar. Efektivitas SPSM-EP menunjukkan peningkatan berpikir kritis dan hasil belajar. Efektivitas SPSM-EP terhadap berpikir kritis siswa ditentukan oleh persentase siswa yang mencapai kriteria ketuntasan minimal tes berpikir kritis. Pikiran kritis siswa meningkat relatif tinggi dalam setiap aktivitas belajar dengan 77,57\%, 83,83\%, 93,45\%. Efektivitas SPSM-EP terhadap hasil belajar siswa ditentukan oleh persentase siswa yang mencapai nilai kognitif, psikomotor dan hasil afektif. Hasil belajar siswa meningkat cukup tinggi yaitu 83,60\%, 88\%, 92\% untuk kognitif, 86\%, 92\%, 92,2\% untuk psikomotor dan $89 \%, 93 \%, 96 \%$ untuk hasil belajar afektif. Para ahli, teman sejawat, mahasiswa, pascasarjana dan guru sarjana bertekad untuk melakukan studi kelayakan untuk SPSM-EP. Para ahli melakukan studi kelayakan untuk SPSM-EP berdasarkan konten, desain dan bahasa. Hasil studi kelayakan dari para ahli adalah 92,5\% untuk materi, 92\% untuk desain dan $100 \%$ untuk bahasa. Hasil studi kelayakan dari teman sejawat, mahasiswa, pascasarjana dan sarjana adalah 96\%, 98\%, 96\% dan 88\%. Hasil studi kelayakan menunjukkan bahwa SPSM-EP layak untuk digunakan bagi siswa.
\end{abstract}

Kata kunci: modul keterampilan proses sains, masalah pencemaran lingkungan, berpikir kritis dan hasil belajar.

\section{Pendahuluan}

IPA merupakan ilmu yang berkaitan dengan cara mencari tahu tentang fenomena alam serta sistematis, sehingga IPA bukan hanya penguasaan kumpulan ilmu pengetahuan yang berupa fakta-fakta, konsep-konsep atau prinsip-prinsip saja, tetapi juga merupakan suatu proses penemuan 
(Kemendikbud, 2013; 175). Hal tersebut menunjukkan bahwa pembelajaran IPA merupakan suatu ilmu yang harus dipelajari melalui pengamatan langsung. Tidak semua materi dapat disampaikan atau cocok menggunakan metode ceramah. Hal tersebut yang menjadi salah satu faktor kurang maksimalnya prestasi siswa dalam pembelajaran. Salah satu pendekatan yang sesuai dengan pembelajaran IPA adalah keterampilan proses sains, hal ini sesuai dengan pendapat Ramesh (2013) yang menyatakan bahwa pendekatan keterampilan proses dapat dilakukan melalui pendekatan inkuiri, penemuan/ penelitian, investigasi yang mana siswa dapat terlibat dalam metode ilmiah, memperoleh pengetahuan dan keterampilan, oleh karena itu keterampilan proses sains perlu digunakan dalam pembelajaran IPA.

Keterampilan proses sains adalah wawasan atau anutan pengembangan keterampilan keterampilan intelektual, sosial, dan fisik yang bersumber dari kemampuankemampuan mendasar yang pada prinsipnya telah ada dalam diri siswa (Dimyati\&Mudjiono,2013;138).

Keterampilan proses sains menitikberatkan pada aktivitas dan kreativitas siswa untuk mengembangkan kemampuan fisik dan mental yang sudah dimiliki ke tingkat yang lebih tinggi dalam memproses perolehan belajarnya (Hamalik, 2013; 150).

Berdasarkan hasil observasi di SMP Negeri 1 Sukolilo dalam kegiatan pembelajaran ditemukan Fakta pertama ditemukan siswa tidak terampil dalam menggunakan alat-alat laboratorium. Fakta kedua kerja sama atau kerja kelompok antar siswa belum baik. Fakta ketiga pada proses pembelajaran masih dominan terpusat pada guru (teacher center), salah satu indikatornya yaitu pembelajaran masih dominan dengan metode ceramah dan siswa lebih sebagai pendengar. Fakta keempat ditemukan bahwa pada saat proses pembelajaran guru seringkali menemukan siswa yang pasif, terlihat pada saat guru memberikan tugas ataupun instruksi untuk menjawab pertanyaan didalam kelas biasanya siswa tidak merespon stimulus yang diberikan guru, hal tersebut menunjukkan guru belum mengajak siswa untuk mengembangkan kemampuan berpikir kritis. Seseorang yang berpikir secara kritis akan mampu mencetuskan gagasan atau menjawab pertanyaan dan mempertahankan gagasan tersebut, disertai dengan pengkajian yang efektif berdasarkan pola penalaran tertentu (Rosana, 2014; 380).

Data Badan Nasional Standar Pendidikan (BNSP) mengenai hasil ujian nasional SMP N 1 Sukolilo tahun 2014/2015 menunjukan bahwa nilai daya serap hasil ujian nasional untuk mata pelajaran IPA tingkat nasional rata-rata 60,31; untuk tingkat provinsi Jawa Tengah rata-rata 55,30; untuk tingkat kabupaten rata-rata 62,63 dan untuk tingkat sekolah rata-rata 54,42. Data lebih spesifik meneganai daya serap materi interaksi dalam ekosistem tingkat provinsi 61,99 ; tingkat nasional 65,29; tingkat kabupaten 66,78 dan tingkat sekolah 66,93. Paparan data tersebut menunjukan bahwa daya serap siswa mata pelajaran IPA masih perlu dioptimalkan dengan cara peningkatan pembelajaran dan penyediaan bahan ajar yang tepat (BNSP, 2015).

Modul merupakan bahan ajar yang terdiri dari satu unit program pembelajaran yang didesain untuk mencapai tujuan pembelajaran. Penelitian tentang pengembangan modul menyatakan bahwa modul yang menyajikan proses pembelajaran Problem Based Learning dapat meningkatkan keterampilan proses sains siswa (Prasasti, 2014). Pembelajaran dalam konteks mempersiapkan sumber daya manusia abad 21 mengacu pada konsep belajar yang memberi 
INKUIRI: Jurnal Pendidikan IPA

Vol. 8, No. 2, 2019 (hal 144-154)

https://jurnal.uns.ac.id/inkuiri

pengalaman pada peserta didik seperti yang dicanangkan UNESCO yaitu "Learning to do, learning to know, learning to be, and learning to live together (Poedjiaji,2010;98), oleh karena itu keterampilan proses sains dapat digunakan untuk mempersiapkan sumber daya manusia pada abad 21 .

Berdasarkan teori tahap

perkembangan Piaget, siswa SMP telah mencapai tahapan operasi formal pada umur 11 sampai dewasa, sehingga mampu untuk berpikir abstrak, berpikir hipotesis, dan alasan logis abstrak (Desmita, 2009; 101).

Kemampuan berpikir kritis adalah model berpikir mengenai hal, substansi atau masalah yang akan meningkatkan kualitas pemikirannya dengan menangani secara terampil struktur-struktur yang melekat dalam pemikiranya dan menerapkan standarstandar intelektual (Fisher, 2009; 4).

Berdasarkan penelitian Sung, H.Y., Hwang, G.J \& Chang, H.S (2015) menyimpulkan bahwa kemampuan berpikir kritis siswa meningkat, maka berbanding lurus dengan hasil belajar siswa. Selain itu manfaat di masa mendatang adalah sebagai bekal dalam persaingan kemajuan teknologi informasi masalah lingkungan hidup, ekonomi berbasis pengetahuan yang membutuhkan kemampuan berpikir kritis (kemendikbud, 2013; 74).

Kemampuan berpikir kritis di indonesia berkategori rendah. Hal ini ditunjukan dengan pada penelitian Syahlita (2016) di SMP N 1 Weru, menunjukan bahwa kemampuan berpikir kiritis siswa rendah, dengan rata-rata 59,86\%. Penelitian Purwanto dkk (2012) di sumedang menyatakan bahwa kemampuan berpikir kritis siswa kategori rendah sebesar 24,2\%, kategori sedang 63,6\% dan kategori tinggi 12,1\%. Penelitian Baskoro (2012) menunjukan bahwa perolehan nilai kemampuan berpikir kritis siswa 40,91, nilai tertinggi 55 dan nilai terendah 25 .
P-ISSN: 2252-7893

E-ISSN: 2615-7489

DOI: 10.20961/inkuiri.v8i2.37753

Penelitian Rosyada (2016) bahwa kemampuan berpikir kritis SMP N 1 Gedangan, Sidoarjo masih sangat kurang optimal dengan rata-rata $51,35 \%$ dengan kategori cukup. Pada proses kegiatan pembelajaran untuk melatihkan kemampuan berpikir kritis yang belum diajarkan guru adalah regulasi diri dan eksplanasi, sehingga secara kulitatif kemampuan berikir kritis di indonesia dalam kategori rendah.

Permasalahan rendahnya kemampuan berpikir kritis siswa juga terjadi di SMP N 1 Sukolilo. Berdasarkan tes kemampuan berpikir kritis menurut facione diperoleh data sebagai berikut; kamampuan interpretasi sebesar 57,56\% dengan kategori cukup, kemampuan analisis sebesar 60,08\% dengan kategori cukup, kemampuan eksplanasi sebesar $40,80 \%$ dengan kategori cukup, kemampuan inferensi sebesar 60,60\% dengan kategori cukup, kemampuan evaluasi sebesar 56,80\% dengan kategori cukup, dan regulasi diri (Self-regulation) sebesar 69,00\% dengan keiteria baik. Rata-rata keseluruhan indikator kemampuan berpikir kritis siswa yaitu $57,47 \%$ dengan kriteria cukup. Hal tersebut menunjukan bahwa kemampuan berpikir kritis siswa di SMP N 1 Sukolilo kurang optimal.

Selain berpikir kritis siswa yang belum optimal, hasil belajar siswa kelas VII di SMP Negeri 1 Sukolilo juga berkategori rendah, ditunjukan dengan hasil ulangan harian materi pencemaran lingkungan semester II tahun ajaran 2014/2015 sebagai berikut; kelas VIIA rata-rata 60,72; kelas VIIB rata-rata 60,40; kelas VIIC rata-rata 63,88; kelas VIID rata-rata 49,96; kelas VIIE ratarata 57,52; dan kelas VIIF ratarata52,16. Rata-rata klasikal seluruh kelas 57,44 dengan kategori cukup.

Hasil analisis kebutuhan siswa menunjukan bahwa; a). Presentase penilaian siswa terhadap cara guru mengajar sudah menarik sebesar $76 \%$, b). Presentase pemakaian laboratorium 
masih kurang dioptimalkan sebesar $92 \%$, c). Presentase praktikum dapat menbantu mempermudah siswa dalam belajar IPA 100\%, d). Siswa diawajibkan memiliki buku pegangan dari sekolah berupa buku paket IPA dan LKS $100 \%$, e). Siswa belum pernah menggunakan modul 100\%, f). Presentase cara belajar IPA dengan dihafalkan dan dipahami $80 \%$, g). Siswa setuju jika dikembangkang modul IPA $100 \%$. Hasil angket kebutuhan siswa menunjukan bahwa bahan ajar IPA di SMP Negeri 1 Sukolilo untuk meningkatkan hasil belajar dan kemampuan berpikir kritis siswa.

Analisis kebutuhan guru menunjukan bahwa; a). Keterbatasan bahan ajar $100 \%$, b). Kendala atau kesulitan dalam menagajar IPA karena katerbatasan bahan ajar 100\%, c). Kebutuhan bahan ajar berupa modul $100 \%$, d).persetujuan pengemabangan modul IPA berbasis keterampilan proses sains $100 \%$.

Kurikulum yang digunakan di SMP N 1 Sukolilo adalah KTSP tentang pencemaran lingkungan pada kompetensi dasar 2.1 mengelompokan sifat larutan asam, larutan basa, garam melalui alat indikator pencapaian kompetensi yang tepat dan 7.4 mengaplikasikan peran manusia dalam pengelolaan lingkungan untuk mengatasi pencemaran dan kerusakan lingkungan.

Berdasarkan pemaparan hasil observasi di SMP N 1 Sukolilo menunjukan bahwa keterampilan proses sains siswa belum optimal dalam pembelajaran dan sumber belajar yang ada selama ini materi IPA belum terpadu. Ketersediaan bahan ajar IPA terpadu yang komperensif menyajikan perpaduan dari berbagai kajian IPA secara utuhsebagai suatu eksatuan yang saling berkaitan adalah mutlak diperlukan. Dilapangan telah beredar buku referensi IPA terpadu namun keterpaduannya yang ada didalamnya belum ada keterhubungan (Connected) masih terpisah-pisah (Fragmented).

Model connected dilaksanakan dengan memadukan atau mengintegrasikan satu konsep, keterampilan, atau kemampuan yang ditumbuhkembangkan dalam satu pokok bahasan yang dikaitkan dengan konsep atau sub konsep pokok bahasan dalam satu bidang studi (Depdiknas, 2008). Materi ajar lebih didekatkan pada situasi dunia nyata sehingga mendorong peserta didik mampu menemukan sendiri berbagai konsep yang dipelajari secara menyeluruh (holistik), bermakna, otentik dan aktif. Selain itu peserta didik juga mampu membuat hubungan antar cabang IPA, dan antara pengetahuan yang dimiliki dengan penerapannya dalam kehidupan sehari-hari. Pengusaan terhadap konsep IPA ini akan membentuk skema kognitif, sehingga anak memperoleh keutuhan dan kebulatan pengetahuan.

Berdasarkan latar belakang tersebut maka akan dilakukan penelitian mengenai "Pengembangan Modul IPA Terpadu Berbasis Keterampilan Proses Sains Untuk Meningkatkan Hasil Belajar dan Kemampuan Berpikir Kritis Siswa Materi Pencemaran Lingkungan Kelas VII SMP N 1 Sukolilo".

Tujuan penelitian ini adalah untuk mendiskripsikan karakteristik modul yang dikembangkan, menguji kelayakan serta keefektifan modul IPA terpadu berbasis keterampilan proses sains pada materi pencemaran lingkungan untuk meningkatkan hasil belajar dan kemampuan berpikir kritis siswa kelas VII di SMP N 1 Sukolilo.

\section{Metode Penelitian}

Penelitian yang dilakukan adalah penelitian pengembangan atau research amd development $(R \& D)$ yang bertujuan untuk mengetahui karakteristik, kelayakan dan keefektifan modul IPA terpadu berbasis 
keterampilan proses sains materi pencemaran lingkungan. Model pengembangan modul pada penelitian ini menggunakan Four-D yang dikembangkan oleh Thiagarajan (1974 ;5).Pengembangan modul dengan model Four-D terdiri dari empat tahapan, meliputi: pendefinisian (define), perancangan (design), pengembangan (develope), dan penyebaran (disseminate). Instrumen penilaian yang digunakan pada penelitian ini adalah lembar angket analisis kebutuhan, lembar tes kemampuan berpikir kritis berupa soal uraian, lembar tes hasil belajar berupa soal pilihan ganda, lembar validasi ahli, lembar penilaian modul oleh siswa dan guru, lembar pengamatan sikap dan keterampilan siswa. Pada tahap awal dilakukan penyebaran angket kebutuhan kepada guru dan siswa mengenai pembelajaran IPA di SMP Negeri 1 Sukolilo.

Pada tahap awal (define) dilakukan penyebaran angket kebutuhan kepada guru dan siswa, mengenai pembelajaran IPA di SMP Negeri 1 Sukolilo. Hasil angket kebutuhan siswa dan guru adalah masih minimnya sumber belajar IPA di sekolah, terkendala atau kesulitan dalam mengajar IPA karena keterbatasan bahan ajar, siswa belum pernah menggunakan modul dalam memahami materi IPA berbais keterampilan proses sains, siswa dan guru membutuhkan modul yang mendukung pembelajaran yang dapat meningkatkan hasil belajar dan kemampuan berpikir kritis siswa.

Tahap design merupakan proses perangcangan modul IPA terpadu berbasis keterampilan proses sains pada materi pencemaran lingkungan. Tahap perancangan modul terdiri dari; pemilihan format modul, membuat desain awal modul, kemudian menghasilkan draft I modul.

Tahap pengembangan (develope) dimulai dengan validasi produk awal berupa draft I yang telah di validasi oleh ahli, praktisi pendidikan, dan teman sejawat. Hasil validasi dan revisi dari pada validator merupakan draft II, kemudian diimplementasikan pada uji coba terbatas kelas VII-D SMP Negeri 1 Sukolilo sebanyak 9 siswa. Draft II direvisi kemudian menghasilkan draft III, dan diimplementasikan pada uji coba lapangan pada kelas VII-A SMP Negeri 1 Sukolilo sebanyak 25. Hasil uji coba lapangan direvisi menghasilkan produk modul IPA terpadu berbasis keteranpilan proses sains materi pencemaran lingkungan.

Tahap design merupakan proses perangcangan modul IPA terpadu berbasis keterampilan proses sains pada materi pencemaran lingkungan. Tahap perancangan modul terdiri dari; pemilihan format modul, membuat desain awal modul, kemudian menghasilkan draft I modul.

Tahap pengembangan (develope) dimulai dengan validasi produk awal berupa draft I yang telah di validasi oleh ahli, praktisi pendidikan, dan teman sejawat. Hasil validasi dan revisi dari pada validator merupakan draft II, kemudian diimplementasikan pada uji coba terbatas kelas VII-D SMP Negeri 1 Sukolilo sebanyak 9 siswa. Draft II direvisi kemudian menghasilkan draft III, dan diimplementasikan pada uji coba lapangan pada kelas VII-A SMP Negeri 1 Sukolilo sebanyak 25. Hasil uji coba lapangan direvisi menghasilkan produk modul IPA terpadu berbasis keteranpilan proses sains materi pencemaran lingkungan.

Pada tahap penyebaran (disseminate) yang dilakukan pada 5 guru anggota MGMP IPA-Kab. Pati. Setelah modul IPA terpadu berbasis keterampilan proses sains disebarkan, guru memberikan penilaian terdahap modul tersebut untuk mengetahui respon pada modul yang dikembangkan. Penilaian tersebut meliputi aspek desain, keterbacaan, materi dan pengembangan modul. 


\section{Hasil Penelitian dan Pembahasan}

Hasil pada tahap awal (define) adalah analisis kebutuhan terhadap guru dan siswa yang dilakukan di SMP Negeri 1 Sukolilo menunjukan bahwa proses pembelajaran untuk melatihkan kemampuan berpikir kritis sudah pernah diajarkan, tetapi siswa masih membutuhkan arahan guru, selain itu guru dan siswa masih kekurangan sumber belajar untuk mengoptimalkan kemampuan berpikir kritis siswa. Dalam hasil observasi menunjukan bahwa guru sudah melatihkan kemampuan berpikir kritis kepada siswa tetapi pendekatan keterampilan proses sains masih jarang dilakukan sehingga kemampuan berpikir kritis siswa belum optimal.

Pada tahap perencanaan adalah desain awal modul yang berisi cover, halam awal, halam francis, kata pengantar, langkah pembelajaran berbasis keterampilan proses sains, gambaran umum, daftar isi, glosarium, pendahuluan, peta konsep, kegiaran belajar (I,II,III), evaluasi. Yang menghasilkan draft I

Pada tahap pengembangan adalah hasil validasi draft I oleh ahli, teman sejawat dan praktisi pendidikan. Presentase aspek penilaian pada modul yaitu aspek keterbacaa $100 \%$ dengan kategori sangat baik,; aspek pengembangan modul sebesar $92 \%$ dengan kategori sangat baik; aspek materi sebesar 92,5\% dengan kategori sangat baik; aspek perangkat pembelajaran (RPP) sebesar 96,25\% dengan kategori sangat baik; teman sejawat sebesar $94,75 \%$ dan $99 \%$ dengan kategori sangat baik; praktisi pendidikan sebesar 98\% dengan kategori sangat baik, dan soal berpikir kritis sebesar 97,5\% dengan kategori sangat baik. sehingga modul tersebut memenuhi kriteria sangat layak untuk digunakan dalam pembelajaran. Tahap ini akan menghasilkan draft II.

Tabel 1. Hasil Revisi Validasi Modul Oleh Validator

\begin{tabular}{|c|c|c|}
\hline No. & Sebelum revisi & Sesudah Revisi \\
\hline \multicolumn{3}{|c|}{ Validator Ahli Materi } \\
\hline 1. & \begin{tabular}{ll}
\multicolumn{2}{l}{ Penambahan } \\
kosakata pada \\
glosarium $3 \mathrm{R}$ \\
(Recycle, \\
$\begin{array}{l}\text { Reduce, dan } \\
\text { Reuse) }\end{array}$
\end{tabular} & $\begin{array}{lr}\text { Sudah } & \text { dilakukan } \\
\text { penambahan } & \text { pada } \\
\text { glosarium (3R) }\end{array}$ \\
\hline 2. & $\begin{array}{l}\text { Penulisan Siklus } \\
\text { pada hujan asam } \\
\text { diberi } \\
\text { keterangan }\end{array}$ & $\begin{array}{l}\text { Sudah diberi keterangan } \\
\text { untuk siklus hujan asam }\end{array}$ \\
\hline 3. & $\begin{array}{l}\text { Gambar } \\
\text { indikator } \\
\text { universal } \\
\text { diperjelas }\end{array}$ & $\begin{array}{l}\text { Gambar } \\
\text { diperjelas }\end{array}$ \\
\hline 4. & $\begin{array}{l}\text { Gunakan } \\
\text { kalimat } \quad \text { yang }\end{array}$ & $\begin{array}{lr}\text { Sudah } & \text { diperbaiki } \\
\text { penggunaan } & \text { kalimat }\end{array}$ \\
\hline & $\begin{array}{l}\text { sederhana } \\
\text { (kalimat efektif) }\end{array}$ & $\begin{array}{l}\text { yang sederhana dan } \\
\text { efektif }\end{array}$ \\
\hline \multicolumn{3}{|c|}{ Validator ahli Keterbacaan Modul } \\
\hline 1. & $\begin{array}{l}\text { Penulisan } \\
\text { kalimat, simbol, } \\
\text { angka, tanda } \\
\text { baca, } \\
\text { disesuaikan } \\
\text { dengan EYD }\end{array}$ & $\begin{array}{l}\text { Sudah diperbaiki } \\
\text { penulisan sesuai dengan } \\
\text { EYD }\end{array}$ \\
\hline 2. & $\begin{array}{l}\text { Pemberian spasi } \\
\text { harus konsisten }\end{array}$ & $\begin{array}{l}\text { Pemberian spasi sudah } \\
\text { konsisten }\end{array}$ \\
\hline 3. & $\begin{array}{l}\text { Gambaran } \\
\text { umum pada } \\
\text { modul diperbsar } \\
\text { sesuai dengan } \\
\text { pedoman } \\
\text { keterbacaan }\end{array}$ & $\begin{array}{l}\text { Gmabarn modul sudah } \\
\text { diperjelas/diperbesar }\end{array}$ \\
\hline \multicolumn{3}{|c|}{ Validator Ahli Pengembangan Modul } \\
\hline 1. & $\begin{array}{l}\text { Pemberian judul } \\
\text { dalam }\end{array}$ & $\begin{array}{lll}\begin{array}{l}\text { Sudah } \\
\text { dalam }\end{array} & \text { diberi judul } \\
\end{array}$ \\
\hline 2. & $\begin{array}{l}\text { Pada } \\
\text { pendahuluan } \\
\text { diberi deskripsi } \\
\text { singkat tentang } \\
\text { modul }\end{array}$ & $\begin{array}{l}\text { Sudah diberi deskripsi } \\
\text { singkat tentang modul }\end{array}$ \\
\hline 3. & $\begin{array}{l}\text { Peta konsep } \\
\text { dibuat sistematis } \\
\text { dan lebih mudah } \\
\text { dipahami }\end{array}$ & $\begin{array}{l}\text { Peta sudah dibuat } \\
\text { sistemtis dan mudah } \\
\text { dipahami }\end{array}$ \\
\hline 4. & $\begin{array}{l}\text { Diberi kalimat } \\
\text { penghubung } \\
\text { pada bagian } \\
\text { prediksi ke } \\
\text { tahap percobaan }\end{array}$ & $\begin{array}{l}\text { Sudah diberi kalimat } \\
\text { penghubung } \\
\text { prediksi ke } \\
\text { percobaan }\end{array}$ \\
\hline 5. & $\begin{array}{lr}\text { Penulisan } & \text { kata } \\
\text { pengantar } & \text { dan } \\
\text { daftar } & \text { isi } \\
\text { diperbaiki } & \\
\text { sesuai EYD } & \\
\end{array}$ & $\begin{array}{l}\text { Penulisan sudah } \\
\text { disesuaikan EYD }\end{array}$ \\
\hline
\end{tabular}

Pada tahap ini uji coba terbatas dilakukan untuk mengetahui 
INKUIRI: Jurnal Pendidikan IPA

Vol. 8, No. 2, 2019 (hal 144-154)

https://jurnal.uns.ac.id/inkuiri

keterbacaan modul dan hasil pengerjaan siswa dan masukan langsung terhadap modul. Siswa uji coba terbatas adalah 12 anak kelas VIID yang dipilih secara acak dengan persentase $78,59 \%$ yang artinya penguasaan siswa baik dan modul layak digunakan pada uji coba lapangan.

Pada tahap uji coba lapangan dianalisis sebagai draft III dilakukan untuk memperoleh hasil pengerjaan modul pada soal berpikir kritis I, soal berpikir kritis II, dan soal berpikir kritis III yang dilakukan oleh siswa. Sampel pada kelas ini adalah 25 siswa kelas VIIA SMP Negeri 1 Sukolilo.

Hasil uji coba terbatas modul dapat dilihat dari pekerjaan siswa terhadap modul IPA terpadu berbasis keterampilan proses sains. Keterbacaan modul dapat dilihat dari dua aspek yaitu kemampuan berpikir kritis dan hasil belajar siswa aspek pengetahuan. Hasil keterbacaan siswa modul IPA terpadu berbasis keterampilan proses sains pada materi pencemaran lingkungan melibatkan 4 siswa pada masing-masing kegiatan belajar. Pada kegiatan belajar I memperoleh presentase sebesar 74,96\% dengan kategori baik, Kegiatan belajar II sebesar 79,01 dengan kategori baik, dan kegiatan belajar III sebesar $81,81 \%$ dengan katogori baik. Rata-rata keseluruhan kegiatan belajar sebesar 80,06 dengan kategori baik. pada aspek hasil belajar pada kegiatan belajar I memperoleh nilai sebesar 82,50\% dengan kategori baik, kegiatan belajar II sebesar $87,50 \%$ dengan kategori baik, dan pada kegiatan belajar III sebesar $80,00 \%$ dengan kategori baik, rata-rata keseluruhan nilai aspek pengetahuan yaitu $83,33 \%$ dengan kategori baik. dapat disimpulkan bahwa keterbacaan modul IPA terpadu berbasis keterampilan proses sains baik.

Modul diimplementasikan dalam pembelajaran IPA di SMP Negeri 1 Sukolilo pada siswa kelas VII-A dengan jumlah 25 siswa menggunakan
P-ISSN: 2252-7893

E-ISSN: 2615-7489

DOI: 10.20961/inkuiri.v8i2.37753

pre-experimental design jenis One-Shot Case Study, artinya terdapat suatu kelompok yang diberikan perlakuan/treatment dan selanjutnya diobservasi hasilnya (Sugiono,2011;73). Implementasi modul IPA terpadu berbasis keterampilan proses sains bertujuan untuk mengetahui keefektifan modul yang dapat dilihat dari nilai rerata kemampuan berpikir kritis yang tinggi (Daryanto,2013;22) dan ketuntasan hasil belajar siswa berdasarkan KKM dari setiap kegiatan belajar yang ada di dalam modul.

Adapun data hasil implementasi dijelaskan pada gambar grafik berikut:

1. Data Kemampuan Berpikir Kritis

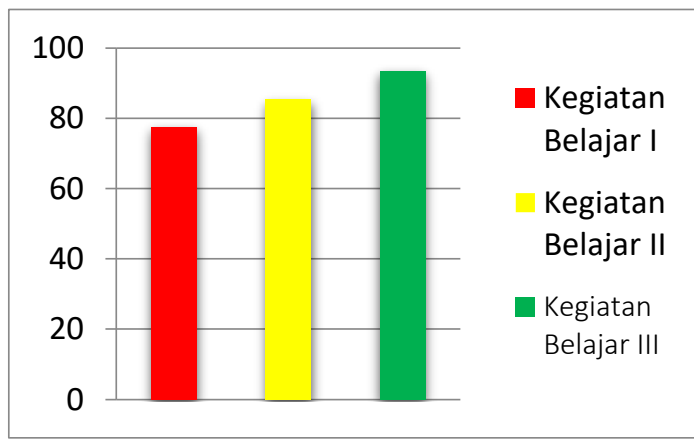

Gambar 1. Grafik peningkatan kemampuan berpikir kritis

Rata-rata kemampuan berpikir kritis siswa pada kegiatan belajar I adalah $77,57 \%$ dengan kategori cukup, kegiatan belajar II mengalami peningkatan sebesar $85,50 \%$ dengan kategori baik, dan pada kegiatan belajar III juga mengalami peningkatan sebesar 93,45\% dengan kategori sangat baik. rata-rata keseluruhan sebesar 85,57 dengan kategori baik.

Rata-rata kemampuan berpikir kritis siswa pada uji coba terbatas dan uji coba lapangan mengalami peningkatan. Pada uji coba terbatas sebsar $80,06 \%$ dan pada uji coba lapangan sebesar $85,57 \%$, terdapat peningkatan sebesar $5,51 \%$ hal tersebut menunjukan bahwa modul efektif digunakan dalam pembelajaran IPA karena tingkat penguasaan atau 
pemahaman siswa terhadap presentase capaian tinggi. Hal tersebut sesuai dengan pendapat Daryanto $(2013 ; 22)$ bahwa keefektifan modul dapat dilihat dari tingkat keterbacaan yang tinggi serta sesuai dengan kemampuan atau penguasaaan pemahaman siswa terhadap modul yang dikembangkan.

\section{Data Hasil Belajar Aspek} Pengetahuan

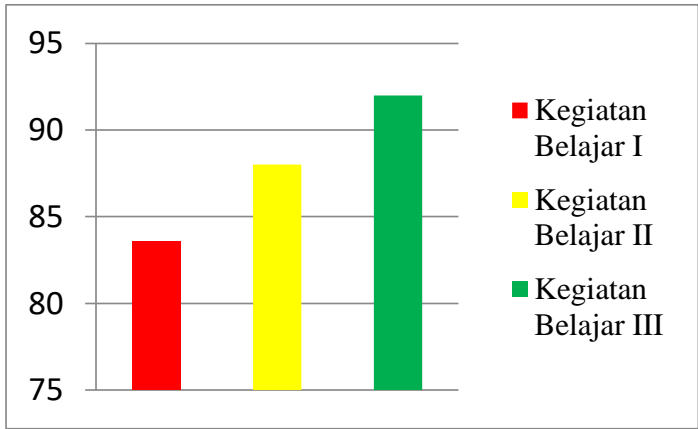

Gambar 2. Grafik Peningkatan Belajar Aspek Pengetahuan

Keefektifan modul terhadap hasil belajar siswa dalam pembelajaran menggunakan KKM pada setiap kegiatan belajar. Rata-rata hasil belajar siswa aspek pengetahuan pada kegiatan belajar I sebesar 83,60 yang dikonversi menurut Permendikbud Nomer 104 Tahun 2014 menjadi 3,34 dengan kriteria baik. Hasil tersebut mengalami peningkatan pada kegiatan belajar II menjadi 88,00 dikonversi menjadi 3,52 dengan kriteria baik. Pada kegiatan belajar III juga mengalami peningkatan sebesar 92,00 dikonversi menjadi 3,68 dengan kriteria sangat baik.

\section{Data Hasil Belajar Aspek} Keterampilan

Penilaian keterampilan siswa mencakup dua aspek yaitu keterampilan konkrit dan keterampilan abstrak. Pada aspek keterampilan konkrit meliputi kelengkapan siswa dalam kelengkapan bahan dalam praktikum, sedangkan aspek keterampilan abstrak meliputi penyajian hasil diskusi dan cara mengkomunikasikan hasil diskusi.

\section{Hasil Belajar Aspek Keterampilan}

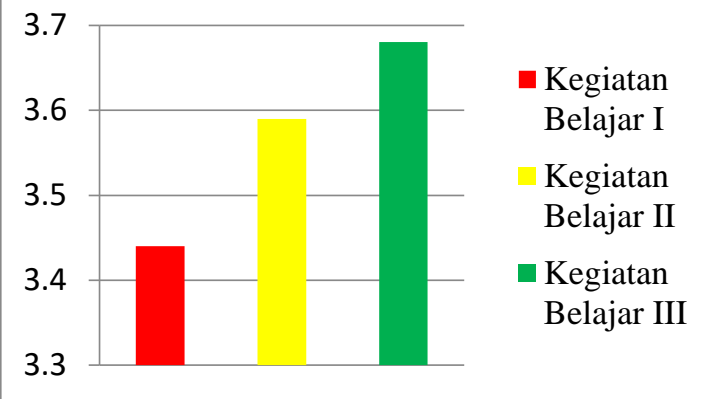

Gambar 3. Grafik Peningkatan Hasil Belajar Aspek Keterampilan

Penilaian keterampilan siswa selama pelaksanakan pembelajaran menggunakan lembar observer yang dilakukan oleh observer dan diakhir pembelajaran di rata-rata dari hasil kegiatan belajar satu sebesar 3,44 dengan kriteria baik, kegiatan belajar dua sebesar 3,59 dengan kriteria sangat baik, dan kegiatan belajar tiga sebesar 3,68 dengan kriteria sangat baik. Dari data tersebut menunjukan bahwa terjadi peningaktan pencapaian katerampilan dari kegiatan belajar satu sampai tiga. Peningkatan tersebut menunjukan bahwa penggunaan modul IPA terpadu berbasisi keterampilan proses sains pad materi pencemaran lingkungan dapat meningkatkan keterampilan siswa.

4. Data Hasil Belajar Aspek Sikap

Hasil belajar siswa pada sikap aspek menurut Permendikbud Nomer 104 tahun 2014 mencakup dua yaitu sikap secara spiritual yang berhubungan dengan iman dan bertakwa implementasinya adalah berdoa sebelum pelajaran dimulai serta kompetensi sikap secara sosial yang meliputi teliti, tanggung jawab, proaktif, santun, dan percaya diri. 


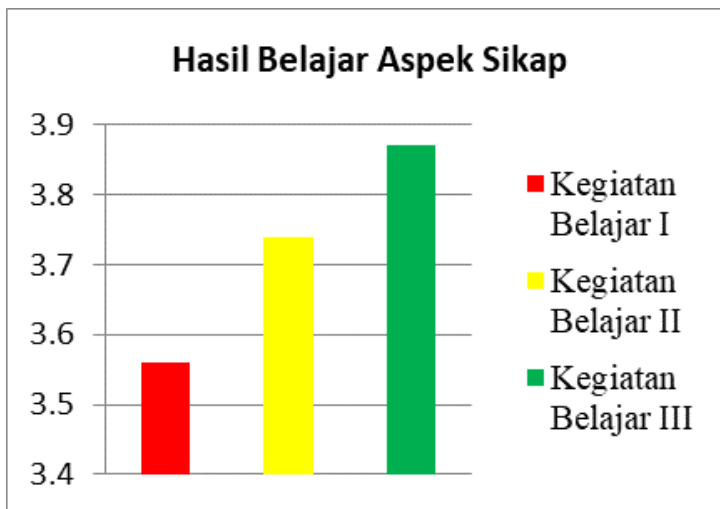

Gambar 4. Grafik Peningkatan Hasil Belajar Aspek Sikap

Rata-rata dari hasil belajar aspek sikap pada kegiatan belajar I sebesar 3,56 dengan kriteria sangat baik, kegiatan belajar II sebesar 3,74 dengan kriteria sangat baik, dan kegiatan belajar III sbesar 3,87 dengan kriteria sangat baik. Dari data tersebut menunjukan hasil pengamatan aspek sikap yang meliputi sikap spiritual dan sosial mengalami peningkatan pada tiap kegiatan belajar. Peningakatan aspek spiritual tersebut didorong oleh kesadaran setiap siswa karena pada setiap pertemuan dan modul disajikan fenomena nyata yang ada disekitar siswa sehari-hari. Peningkatan pada aspek sosial didorong oleh kesadaran siswa untuk memperoleh data yang sebenarnya, dengan bekerja sama dalam satu kelompok kerja. Pembelajaran menggunakan modul IPA terpadu berbasis keterampilan proses sains materi pencemaran lingkungan dapat meningkatkan aspek sikap spiritual dan sosial siswa.

5. Data Repon Guru dan Siswa Terhadap Modul

Respon siswa terhadap modul IPA terpadu berbasis keterampilan proses sains adalah sangat baik. angket diberikan kepada 25 siswa di kelas VIIA mencakup dua pernyataan negarif dan positif. Jumlah pernyataan negatif ada 11 item dan pernyataan negatif ada 10 item. Respon siswa pada pernyataan positif sebesar 3,55 yang berarti modul sangat baik, sedangkan pernyataan negatif sebesar 1,44 yang berarti modul sangat baik.

Pada tahap penyebaran (disseminate) modul diberikan kepada 5 guru anggota MGMP-SMP Kabupaten Pati.Tujuan tahap ini adalah untuk mendapatkan tanggapan terhadap modul IPA terpadu berbasis keterampilan proses sains pada materi pencemaran lingkungan yang telah dikembangkan. Guru diberikan modul IPA terpadu berbasis keterampilan proses sains materi pencemaran lingkungan, kemudian diberikan angket yang berisi respon guru terhadap modul yang dikembangkan. Hasil respon guru terhadap modul IPA terpadu berbasis keterampilan proses sains mendapatkan rata-rata 3,87 dengan kategori sangat baik.

\section{Kesimpulan dan Rekomendasi}

Berdasarkan hasil penelitian dan pembahasan dapat disimpulkan:

1. Karakteristik modul IPA terpadu berbasis keterampilan proses sains pada materi pencemaran lingkungan dikembangkan berdasarkan komponen pendekatan keterampilan proses sains dengan format kriteria modul yang diadaptasi dari Daryanto dan merujuk pada standar yang ditetapkan oleh BSNP tentang standart pengembangan buku teks. Kegiatan belajar memuat KD 2.1 Mengelompokan sifat larutan asam, larutan basa, dan larutan garam melalui alat dan indicator pencapaian kompetensi, KD 2.2 Melakukan percobaan sederhana dengan bahan-bahan yang diperoleh dalam kehidupan sehari-hari, dan KD 7.4 Mengaplikasikan peran manusia dalam pengelolaan lingkungan untuk mengatasi pencemaran lingkungan dan kerusakan lingkungan. Hasil penelitian menunjukan bahwa modul membantu siswa dalam 
belajar mandiri, menghubungkan antara pengetahuan yang dimiliki dengan penerapan dalam kehidupan sehari-hari sehingga dapat meningkatkan hasil belajar dan kemampuan berpikir kritis siswa.

2. Kelayakan modul IPA berbasis keterampilan proses sains materi pencemaran lingkungan dapat dilihat dari penilaian ahli, praktisi pendidikan, dan teman sejawat. Persentase penilian pada modul yaitu pengembangan modul sebesar 92\% dengan kategori sangat baik yaitu tampilan dan isi modul, penyajian modul, kecernaan modul, perhatian terhadap kode etik dan hak cipta; bahasa sebesar $100 \%$ dengan kategori sangat baik yaitu kesesuian bahasa dengan tingkat perkembangan siswa, komunikatif dan sederhana; materi sebesar 92,5\% dengan kategori sangat baik yaitu kelengkapan materi, keakuratan materi, kegiatan yang mendukung pembelajaran, materi mengembangkan keterampilan proses sains dan kemampuan berpikir kritis. Penilaian modul pada uji coba terbatas dan uji coba lapangan sebesar $78,59 \%$ dan $85,67 \%$ dengan kategori baik artinya penguasaan siswa baik.

3. Keefektifan modul dalam pembelajaran menggunakan presentase jumlah siswa yang mencapai KKM pada setiap kegiatan belajar mengalami peningkatan kemampuan berpikir kritis. Pada kegiatan belajar I memperoleh presentase sebesar $77,57 \%$ dengan kategori baik, kegiatan belajar II sebesar $85,50 \%$ dengan kategori baik, dan kegiatan belajar III sebesar 93,45\% dengan kategori sangat baik. Aspek kemampuan berpikir kritis tertinggi pada aspek interpretasi. $\mathrm{Hal}$ tersebut membuktikan bahwa modul IPA berbasis keterampilan proses sains pada materi pencemaran lingkungan efektif digunakan dalam pembelajaran.

Berdasarkan penelitian yang telah dilakukan, maka perlu perbaikan dan saran dalam pemanfaatan produk lebih lanjut, antara lain:

1. Modul IPA terpadu berbasis keterampilan proses sains dapat digunakan dalam pembelajaran pada materi pencemaran lingkungan kelas VII SMP/MTs karena telah diujicobakan dengan hasil yang baik.

2. Hasil penelitian hanya dilaksanakan pada siswa SMP Negeri 1 Sukolilo, sehingga perlu dillakukan penelitian di sekolah untuk mendapatkan data yang bervariasi.

\section{Daftar Pustaka}

Baskoro Adi Prayitno, dkk. 2012. Prototipe Pembelajaran KonstruktivisKolaboratif untuk Memberdayakan Kemampuan Berpikir Kritis dan Keterampilan Proses Sains Siswa Akademik Bawah. Surakarta: Universitas Sebelas Maret.

BNSP. 2015. Laporan Hasil Ujian Nasional Tahun 2014/2015. Jakarta: Kementrian Pendidikan dan Kebudayaan.

Daryanto. 2013. Menyusun Modul Bahan Ajar Untuk Persiapan Guru Dalam Mengajar. Yogjakarta: Gava Media.

Desmita. 2009. Psikologi Perkembangan Peserta Didik. Bandung: PT. Remaja Rosyada.

Dimyati dan Mudjiono. 2013. Belajar dan Pembelajaran. Jakarta: Rineka Cipta.

Depdiknas. 2008. Penulisan Modul. Jakarta: Depdiknas.

Ficher, Alec. 2009. Berpikir Kritis: Sebuah Pengantar. Jakarta: Erlangga.

Hamalik, Oemar. 2013. Proses Belajar Mengajar. Jakarta : Bumi Aksara. 
Kemendikbud. 2013. Kurikulum 2013. Jakarta: Kementerian Pendidikan dan Kebudayaan.

Poedjiadi, Anna. 2010. Sains danTeknologi Masyarakat. Bandung: PT Remaja Rosdakarya.

Prasasti, Pinkan Amati Ari. 2014 Pengembangan Modul Berbasis Problem Based Learning (PBL) Disertai Fishbone Diagram Pada Materi Pencemaran Lingkungan Untuk

Memberdayakanketerampilan

Proses Sains (KPS) Dan Kemampuan Menganalisis (penelitian pengembangan di SMA Negeri 2 Karang Anyar Tahun Pelajaran 2013/2014). Thesis: Universitas Sebelas Maret

Purwanto, dkk. 2012. Implemetasi Permainan Monopoli Fisika Sebagai Media Pembelajaran dalam Pembelajaran Kooperatif Tipe TGT untuk Meningkatkan Prestasi Belajar dan Mengetahui Profil Kemampuan Berpikir Kritis Siswa SMP. Jurnal Pengajaran MIPA, Volume 17 Nomor 1 April 2012, halaman 69-76. Bandung: FPMIPA, Universitas Pendidikan Indonesia.

Ramesh, M., \& Patel, R.C. 2013. Critical Pedagogy for Constructing Knowledge and Process Skills in Science. Journal Educationia Confab, 2 (1): 98- 105.

Rosana, Dadan. 2014. Pendekatan Saintifik dalam Pembelajaran IPA Secara Terpadu. Yogjakarta: Universitas Negeri Yogjakarta.

Rosyada, Alfath Rokhim. 2016. Pengembangan Modul IPA Berbasis Problem Based Learning pada Materi Kalor dan Perpindahan Untuk Meningkatkan Keterampilan Berpikir Kritis Siswa SMP Kelas VII. Thesis: Universitas Sebelas Maret.

Sugiyono. 2011. Metode Penelitia Pendidikan Pendekatan Kuantitatif, Kualitatif, danR \& D. Bandung: Alfabeta.
Sung, H. Y, Hwang G. J \& Chang, H.S. 2015. An Integrated Contextual and Web-based Issue Quest Approach to Improving Students' Learning Achievement, Attitude and Cricital Thingking. Educational Technology \& Society, 18 (4), 299311.

Syahlita, Imega Dewi. 2016. Pengembangan Modul IPA Berbasis Saintifik Untuk Meningkatkan Keterampilan Berpikir Kritis dan Hasil Belajar Siswa. Thesis: Universitas Sebelas Maret.

Thiagarajan, S. Semmel, D.S \& Semmel, MI. $\quad 1974 . \quad$ Instructional Development for Training Teachers of Exceptional Children. Indiana: Indiana University Bloomington. 